\title{
Current views on molecularly targeted therapy for lung cancer - a review of literature from the last five years
}

\author{
Agnieszka Rybarczyk-Kasiuchnicz ${ }^{1}$, Rodryg Ramlau ${ }^{2}$ \\ ${ }^{1}$ Department of Oncology and Pulmonology, Greater Poland Center of Pulmonology and Thoracic Surgery, \\ Poznan, Poland \\ ${ }^{2}$ Department of Oncology and Pulmonology, Poznan University of Medical Sciences, Poznan, Poland
}

Kardiochirurgia i Torakochirurgia Polska 2018; 15 (2): 119-124

\begin{abstract}
Lung cancer is the main cause of cancer-related deaths in Poland. Epidermal growth factor receptor tyrosine kinase inhibitors (EGFR-TKIs) are a new group of agents for non-small-cell lung cancer (NSCLC) patients. Determining the predictive value of activating mutations in the EGFR and ROS-1 genes and ALK rearrangement in non-small-cell lung cancer has enabled the identification of patients likely to achieve true clinical benefits. EGFR-TKIs may produce objective response in more than $60 \%$ of patients and prolong progression-free survival to 10 months in mutation-positive patients. No improvement of overall survival was shown in randomized trials. The era of immunotherapy implementing PD-1 and PD-L1 inhibitors has changed the face of lung cancer therapy. We aimed to review the literature on the use of EGFR-TKIs and immunotherapeutic agents for NSCLC patients.
\end{abstract}

Key words: non-small-cell lung cancer, growth factor receptor tyrosine kinase inhibitors, ALK-rearrangement, immunotherapy.

\section{Introduction}

Lung cancer is one the most common types of malignant neoplasms in Poland. It is also the main cancerrelated cause of death in this country. In total, over 22,000 new cases of lung cancer are recorded each year. According to the Polish National Cancer Registry, the rate of 5-year survival among lung cancer patients for the year 2016 was 13\% [1]. The most significant prognostic factor in the course of this disease is its advancement. In patients after radical surgery, the median duration of overall survival (OS) is 14-60 months; for advanced stages, this time ranges from several months to over a year. For

\section{Streszczenie}

Rak płuca stanowi główną przyczynę zgonów z powodu nowotworów złośliwych w Polsce. Inhibitory kinaz tyrozynowych (TKI) związanych z receptorem naskórkowego czynnika wzrostu są nową grupą leków stosowanych u chorych na niedrobnokomórkowego raka płuca (NDRP). Ustalenie znaczenia predykcyjnego mutacji aktywujących w genie EGFR, w genie ROS-1 i rearanżacji genu ALK umożliwiło wyodrębnienie grupy chorych odnoszących rzeczywiste korzyści kliniczne z tej terapii. U chorych z mutacją aktywującą EGFR lub z obecnością genu fuzyjnego EML4/ALK otrzymujących leki z grupy TKI uzyskuje się ponad $60 \%$ obiektywnych odpowiedzi oraz wydłużenie czasu przeżycia wolnego od progresji do 10 miesięcy. W badaniach z losowym doborem chorych nie stwierdzono dotychczas wpływu TKI na czas przeżycia całkowitego. W erze immunoterapii, kiedy wprowadzono inhibitory PD-1 i PD-L1, zmienił się charakter leczenia raka płuc. Celem opracowania był przegląd piśmiennictwa dotyczącego zastosowania TKI i immunoterapii u chorych na NDRP.

Słowa kluczowe: niedrobnokomórkowy rak płuca, inhibitory kinazy tyrozynowej receptora naskórkowego czynnika wzrostu, gen fuzyjny ALK-EML4, immunoterpia.

the past few years, the incidence of adenocarcinoma has been observed to gradually increase, while the incidence of squamous cell carcinoma has shown a falling tendency. The use of two-drug regimens based on platinum derivatives and new-generation agents offers a chance to achieve an OS of 10 to 12 months. Conventional chemotherapy regimens fail to achieve significant prolongation of patient survival. The treatment's toxicity, rising with its duration, not only worsens the patients' quality of life, but also limits therapeutic options. To help these patients, researchers have begun to develop new treatment strategies based on molecular biology [2].

Address for correspondence: Agnieszka Rybarczyk-Kasiuchnicz MD, Department of Oncology and Pulmonology, Greater Poland Center of Pulmonology and Thoracic Surgery, St Ludwikowo n. Poznań, 62-050 Mosina, Poland, phone: +48 501 546 086, e-mail: agnieszka.rybarczyk3@wp.pl Received: 4.01.2018, accepted: 25.02.2018. 


\section{Activating mutations in the EGFR gene - first-generation tyrosine kinase inhibitors}

Starting in the year 2000, patients with lung cancer in the Massachusetts General Hospital received gefitinib in monotherapy after being previously treated with chemotherapy. The average time of survival during the gefitinib treatment exceeded 18 months, and the treatment lasted 16 months on average. The study showed that most of the patients who responded to gefitinib treatment were nonsmoking women diagnosed with bronchoalveolar cancer. A hypothesis was put forward that patients with nonsmall-cell lung carcinoma (NSCLC) responding to gefitinib have a somatic mutation in the EGFR gene, which provides them with sensitivity to the employed agent. After the gene's entire coding region was sequenced using the polymerase chain reaction (PCR) method in patients responding to gefitinib, mutations were found in exons 18, 19, and 21. Based on these results, FDA approved gefitinib (a lowmolecular-weight inhibitor of epidermal growth factor receptor's tyrosine kinase domain) for the treatment of lung cancer. This is the first medication for this disease with an identified molecular target. Pharmacological studies have enabled the establishment of the recommended daily dose at $250 \mathrm{mg}$.

\section{EGFR tyrosine kinase inhibitors as a first-line treatment for patients with activating mutations in the EGFR gene}

Eight phase III clinical trials analyzing patients with advanced NSCLC demonstrated advantages of gefitinib, erlotinib, and afatinib over two-drug chemotherapy based on platinum derivatives and new-generation cytostatics. In the IPASS study, gefitinib was compared with carboplatin and paclitaxel, in the West-Japan study - with cisplatin and docetaxel, in the North-East-Japan study - with carboplatin and paclitaxel, and in the First-SIGNAL study - with cisplatin and gemcitabine. In the OPTIMAL and EURTAC trials erlotinib was compared with two-drug chemotherapy regimens (respectively: gemcitabine with carboplatin and a two-drug regimen based on platinum derivatives). In turn, the LUX-Lung 3 study compared afatinib with a combination of cisplatin and pemetrexed [3], while the LUX-Lung 6 study compared it with a combination of cisplatin and gemcitabine [4]. All these studies showed advantages of tyrosine kinase inhibitors (TKIs) over two-drug chemotherapy based on platinum derivatives and new-generation agents. The patients receiving TKIs achieved longer progression-free survival (PFS) and had higher objective response rates (ORR) and disease control rates (DCR) in comparison to patients treated with chemotherapy. Firstgeneration TKIs block the EGFR receptor in a reversible fashion. Afatinib binds to the receptor irreversibly and has higher receptor affinity [5]. The LUX-Lung 7 trial compared gefitinib with afatinib in patients with metastases to the central nervous system (CNS). The average time of followup was 27.3 months; progression-free survival amounted to 11 months in the afatinib group and 10.9 months in the gefitinib group. The average time to treatment failure was 13.7 months for afatinib and 11.5 months for gefitinib. The trial showed no differences between the agents in terms of overall survival [6].

Dacomitinib, an irreversible second-generation panHER TKI was compared with first-generation TKIs in clinical studies ARCHER 1009 and ARCHER 1028, which analyzed patients who had been previously treated. The patients receiving dacomitinib had longer progression-free survival, but the treatment's toxicity was higher. In the ongoing ARCHER 1050 study, dacomitinib is being compared with gefitinib as a first-line treatment for patients with advanced lung cancer [7].

\section{T790M mutation}

Treated with gefitinib, erlotinib, or afatinib, NSCLC patients with activating mutations in the EGFR gene exhibit secondary resistance to these agents after an initial period of treatment response. Other patients fail to respond to gefitinib or erlotinib from the outset. The factor underlying this situation is the T790M mutation in exon 20 of the EGFR gene. The mutation conditions $50-60 \%$ of resistance to first- and second-generation TKIs [8].

Osimertinib, a third-generation TKI, was compared in the clinical study AURA 3 to two-drug chemotherapy based on pemetrexed and cisplatin or carboplatin. This was the second line of treatment for all patients; the first line included first- and second-generation EGFR TKIs. After disease progression, the T790M mutation was assessed, and the patients were randomized into two groups, receiving either osimertinib or chemotherapy. The study included patients with metastases to the central nervous system who had no symptoms resulting from focal CNS lesions and required no steroid treatment for at least 4 weeks before the start of the study. The average treatment duration was 10.1 months for patients receiving osimertinib $(n=279)$ and 4.4 months for patients receiving chemotherapy $(n=$ 140). The objective response rate (ORR) amounted to $71 \%$ for osimertinib and 31\% for chemotherapy. Progression-free survival was prolonged in patients receiving osimertinib (as compared to chemotherapy) regardless of the presence of CNS metastasis [9-11].

Osimertinib, a low-molecular-weight third-generation TKI is recommended in patients with the T790M resistance mutation. It is also effective in patients with metastases to the central nervous system and meninges [12-14].

In FLAURA, a phase III clinical study, patients receiving osimertinib achieved PFS of 18.9 months, as compared to 10.2 months achieved in the control group (gefitinib or erlotinib). Patients with CNS metastases also benefited from the osimertinib treatment.

Another phase III study, ADAURA, is currently under way, examining patients with resectable lung cancer (stages IB-IIIA) and the T790M mutation. The patients receive osimertinib as an adjuvant treatment, and the controls are under active follow-up [15]. 


\section{Mechanisms of resistance to osimertinib}

Two mutations responsible for disease progression during osimertinib therapy have been found: G724S [16] and C797S in exon 20 [17]. The mutations condition osimertinib resistance. Brigatinib has been demonstrated to be effective in breaking resistance caused by the C797S mutation [18].

\section{Activating rearrangement in the ALK gene}

Fusion between the EML4 and ALK genes results in the formation of the fusion gene EML4/ALK, which is found in approximately $3-7 \%$ of patients with lung adenocarcinoma. It activates the intracellular transmission pathway, stimulates neoplastic proliferation, and inhibits apoptosis. An activating mutation in the ROS1 gene is found in approximately $1 \%$ of lung adenocarcinoma cases [19]. These mutations occur most often in young patients who either do not smoke tobacco or have a short history of smoking. The presence of these activating mutations is the therapeutic target for the low-molecular-weight selective inhibitor of the ALK and ROS1 tyrosine kinase receptors crizotinib.

A phase III study, PROFILE 1014, compared crizotinib with two-drug chemotherapy (cisplatin and pemetrexed as the first line of treatment). The patients were positive for the ALK/EML4 fusion gene and had diffuse disease. The study achieved PFS of 10.9 months in patients treated with crizotinib and 7 months in patients receiving chemotherapy [20]. In lung adenocarcinoma patients with the ALK rearrangement (the EML4/ALK fusion gene) detected by molecular investigation, crizotinib is recommended as the first line of treatment. Another phase III study, PROFILE 1007, compared crizotinib with one-drug chemotherapy (pemetrexed or docetaxel) administered as a second-line treatment. Progression free survival was 7.7 months in the crizotinib group, as compared with 3 months in the chemotherapy group. Benefits from the crizotinib treatment (in comparison to chemotherapy) also included improved quality of life during the treatment and better symptom control [21]. Lung cancer patients with the ALK gene rearrangement who received chemotherapy as the first line of treatment should be qualified for second-line crizotinib treatment. To a small degree, crizotinib penetrates into the central nervous system. Disease progression in the CNS occurs in approximately half of the patients treated with crizotinib [22].

Ceritinib, a second-generation TKI, works in lung cancer patients with tumors exhibiting ALK gene rearrangement. The multicenter ASCEND-1 study demonstrated its effectiveness in patients previously treated with crizotinib. Progression-free survival lasted 6.9 months, and the ORR amounted to $56 \%$. Patients with CNS metastases also benefited from the treatment [23]. In the crossover ASCEND-5 study, ceritinib was administered to lung cancer patients with ALK rearrangement in the tumor cells (stages IIIBV) after previous chemotherapy, crizotinib treatment, and disease progression. The patients received ceritinib or chemotherapy (pemetrexed or docetaxel). The follow-up was 16.5 months; PFS lasted 5.4 months in patients receiving ceritinib and 1.6 months in patients undergoing chemotherapy. Patients receiving ceritinib showed better tolerance to the treatment, experienced fewer adverse events, and adhered to treatment schedules [24]. Ceritinib is a low-molecular-weight TKI recommended in ALK-positive patients after failed crizotinib treatment or treatment intolerance.

Alectinib, a second-generation TKI, is also effective in the central nervous system in patients with ALK-positive lung tumors. The phase III study ALEX included previously untreated patients with advanced ALK-positive lung cancer. The patients received crizotinib or alectinib. The primary endpoint of the study was the duration of progression-free survival. The median duration of follow-up was 17.6 months in the crizotinib arm, as compared to 18.6 months in the alectinib arm. PFS was significantly longer in patients treated with alectinib and lasted 25.7 months, in comparison to 10.4 months in the crizotinib group. The study also demonstrated alectinib to be effective in patients with metastases to the central nervous system. Changes in the CNS occurred in $12 \%$ of the patients treated with alectinib (18 patients) and in $45 \%$ of patients treated with crizotinib (68 patients). Additionally, the alectinib treatment was associated with lower toxicity [25].

\section{Immunotherapy in lung cancer}

A new therapeutic option for advanced lung cancer consists in blocking the PD-1 receptor on T cells, B cells, or PD-L1 situated on the tumor cells. Immunotherapy restores the immune system's ability to recognize and act against tumor cells, offering a chance to limit the disease's progression. Monoclonal antibodies bind to the PD-1 receptor (pembrolizumab, nivolumab) or the PD-L1 (atezolizumab, durvalumab).

Clinical studies are being conducted on both squamous and non-squamous cell carcinoma.

\section{Squamous lung cancer}

Necitumumab is an IgG1 monoclonal antibody targeting EGFR.

In the clinical study SQUIRE, the addition of necitumumab to chemotherapy (cisplatin with gemcitabine) in the first line of treatment prolonged overall survival among patients with squamous cell lung carcinoma from 9.9 months in the group treated with chemotherapy alone to 11.5 months in the group receiving necitumumab. PFS of 1 year was achieved by $48 \%$ of the patients receiving necitumumab in comparison to $43 \%$ of the patients treated with chemotherapy alone [26]. Retrospective analysis showed that patients with squamous lung carcinoma and tumor EGFR expression benefited from the addition of necitumumab [27].

In the CheckMate 017 study, patients with squamous lung cancer, who had previously been treated, received nivolumab or docetaxel. Overall survival was longer among 
patients receiving nivolumab (mean OS = 9.2 months; 95\% Cl: 7.3-13.3 months) vs. docetaxel (mean OS = 6 months; 95\% Cl: 5.1-7.3 months) [28]. Nivolumab was better tolerated than docetaxel, the dosage was reduced less frequently, and the patients adhered to the treatment schedule; the therapy was discontinued in $3 \%$ of patients receiving nivolumab and $10 \%$ of patients receiving docetaxel [29]. Nivolumab is recommended in squamous lung cancer patients who were previously treated with chemotherapy based on platinum derivatives. Benefits from nivolumab treatment are obtained in patients with PD-L1 expression shown to exceed $1 \%$ by molecular examination of tumor tissues.

\section{Non-squamous lung cancer}

In the INSPIRE study, the addition of necitumumab to chemotherapy (cisplatin with pemetrexed) in non-squamous lung cancer patients did not improve OS or PFS [30].

Pembrolizumab is a monoclonal antibody targeting PD-1 (programmed cell death receptor 1). The phase III study KEYNOTE 010 demonstrated that, in non-squamous lung cancer patients, pembrolizumab employed in the second line of treatment can prolong overall survival in comparison to docetaxel. The authors reported that lung cancer patients in whom the tumor cells showed PD-1 expression of at least $50 \%$ benefited from the therapy [31]. In another phase III study, KEYNOTE 024, the first line of treatment included pembrolizumab or two-drug chemotherapy based on cisplatin. The average PFS was 10.3 months in the pembrolizumab group and 6.7 months in the chemotherapy group. Six-month OS was achieved by $80.2 \%$ of patients treated with pembrolizumab and $72.4 \%$ of patients receiving chemotherapy. The response rates were $44.8 \%$ for pembrolizumab and $27.8 \%$ for chemotherapy. The patients included in the study had PD-L1 expression on at least $50 \%$ of the tumor cells [32]. Based on this study, the FDA approved pembrolizumab as a first-line treatment for patients with non-squamous lung cancer, provided that PD-1 expression in the tumor cells is $50 \%$ or higher according to molecular examinations. This high tumor cell expression is observed in approximately $30 \%$ of patients with NSCLC [33].

In the CheckMate 057 study, non-squamous lung cancer patients received a second-line treatment in the form of nivolumab or chemotherapy (docetaxel alone). The average OS was 12.2 months for nivolumab and 9.4 months for docetaxel. Fewer serious adverse events (SAEs) were noted in the nivolumab group (10\%) than in the docetaxel group (54\%); there was no difference between the groups in terms of PFS [34].

In the CheckMate 026 phase III study, the first line of treatment for NSCLC patients included nivolumab or twodrug chemotherapy based on cisplatin. PD-1 expression in tumor cells was at least 5\%. Progression free survival amounted to 4.2 months in the nivolumab group, as compared to 5.9 months in the chemotherapy group. The duration of OS was 14.4 months for nivolumab and 13.2 months for chemotherapy. Serious adverse events occurred in
$18 \%$ of patients receiving nivolumab and in $51 \%$ of patients treated with chemotherapy [35].

Atezolizumab is a monoclonal antibody binding to the PD-L1 receptor. In the POPLAR phase II study, non-squamous lung cancer patients after progression despite chemotherapy based on platinum derivatives received either atezolizumab or docetaxel [36]. The greatest benefits from atezolizumab were obtained in patients with high PD-L1 expression in the tumor tissues. Overall survival amounted to 15.5 months in the antibody (atezolizumab) group and 11.1 months in the chemotherapy (docetaxel) group; PFS lasted, respectively, 9.7 and 3.9 months. Patients in whom molecular examinations of the tumor tissues did not demonstrate PD-L1 expression had similar OS regardless of the agent employed.

In the OAK phase III study, lung cancer patients who had been previously treated with chemotherapy received atezolizumab or docetaxel in monotherapy. The average OS was 13.8 months (11.8-15.7 months) in the atezolizumab group and 9.6 months (8.6-11.2 months) in the chemotherapy group [37].

PACIFIC, a randomized phase III trial, demonstrated that, in patients with locally advanced NSCLC (stage III) and progression after standard chemoradiotherapy, durvalumab prolonged PFS to 16.8 months (vs. 5.6 months in placebo controls). Grade 3 or 4 adverse events (including pneumonitis) occurred in $4.4 \%$ of patients receiving durvalumab and $3.8 \%$ of placebo controls [38].

Good results in terms of disease control achieved during molecularly targeted therapies encourage researchers to attempt combining chemotherapy with low-molecularweight tyrosine kinase inhibitors. In the LUME Lung-1 study, docetaxel was combined with the tyrosine kinase inhibitor nintedanib in patients with advanced non-squamous lung cancer who had previously been treated. PFS amounted to 3.4 months in the nintedanib group and 2.7 months among patients who did not receive this agent $[39,40]$.

\section{Conclusions}

New strategies of lung cancer treatment, based on molecular diagnosis of the tumor, allow for adjusting the therapy to specific changes in neoplastic cells responding to the administered agents. This enables the achievement of good therapeutic effects, reduction of treatment toxicity, improved progression-free survival, and a chance for prolonging the lives of the patients. The new agents allow the patients to undergo sequential therapy. The occurrence of TKI resistance caused by mutation in the tumor cells does not eliminate the chance for further treatment. Molecular biology offers the opportunity to detect resistance mutations and use next-generation TKIs to break the resistance. Close cooperation between physicians of various specialties should enable quick detection of lung cancer and prompt diagnosis (including the indispensable molecular investigation), while the results of subsequent clinical studies should enable the introduction of new agents into medical practice. 


\section{Disclosure}

\section{Authors report no conflict of interest.}

\section{References}

1. Wojciechowska U, Olasek P, Czauderna K, Didkowska J. Nowotwory złośliwe w Polsce w 2014 r. Krajowy Rejestr Nowotworów, Warszawa 2016.

2. Novello S, Barlesi F, Califano R, Cufer T, Ekman S, Levra MG, Kerr K, Popat S, Reck M, Senan S, Simo GV, Vansteenkiste J, Peters S; ESMO Guidelines Committee. Metastatic non-small-cell lung cancer: ESMO Clinical Practice Guidelines for diagnosis, treatment and follow-up. Ann Oncol 2016; 27 (Suppl 5): V1-V27.

3. Sequist LV, Yang JC, Yamamoto N, O’Byrne K, Hirsh V, Mok T, Geater SL, Orlov S, Tsai CM, Boyer M, Su WC, Bennouna J, Kato T, Gorbunova V, Lee KH, Shah R, Massey D, Zazulina V, Shahidi M, Schuler M. Phase III study of afatinib or cisplatin plus pemetrexed in patients with metastatic lung adenocarcinoma with EGFR mutations. J Clin Oncol 2013; 31: 3327-3334.

4. Wu YL, Zhou C, Hu CP, Feng JF, Lu S, Huang Y, Li W, Hou M, Shi JH, Lee KY, Massey D, Shi Y, Chen J, Zazulina V, Geater SL. LUX-Lung 6: a randomized, open-label, phase III study of afatinib (A) versus gemcitabine/cisplatin (CG) as first-line treatment for Asian patients with EGFR mutation-positive (EGFR M+) advanced adenocarcinoma of the lung. J Clin Oncol 2013; 31: 8016

5. Blackhall F, Cappuzzo F. Crizotinib: from discovery to accelerated development to front-line treatment. Ann Oncol 2016; Suppl 3: i35-i41.

6. Park K, Tan EH, O'Byrne K. Afatinib versus gefitinib as first-line treatment of patients with EGFR mutation-positive non-small-cell lung cancer (LUX-Lung 7): a phase 2B, open-label, randomised controlled trial. Lancet Oncol 2016; 17: 577-589.

7. Zugazagoitia J, Diaz A, Jimenez E. Second-line treatment of non-small cell lung cancer: focus on the clinical development of dacomitinib. Front Med (Lausanne) 2017; 4: 36

8. Santarpia M, Liguori A, Karachaliou N, Gonzalez-Cao M, Daffinà MG, D’Aveni A, Marabello G, Altavilla G, Rosell R. Ozimertinib in the treatment of non-small-cell lung cancer: design, development and place in therapy. Lung Cancer 2017; 8: 109-125.

9. Cross DA, Ashton SE, Ghiorghiu S, Eberlein C, Nebhan CA, Spitzler PJ, Orme JP, Finlay MR, Ward RA, Mellor MJ, Hughes G, Rahi A, Jacobs VN, Red Brewer M, Ichihara E, Sun J, Jin H, Ballard P, Al-Kadhimi K, Rowlinson R, Klinowska T, Richmond GH, Cantarini M, Kim DW, Ranson MR, Pao W. AZD9291, an irreversible EGFR TKI, overcomes T790M-mediated resistance to EGFR inhibitors in ling cancer. Cancer Discov 2014; 4: 1046-1061.

10. Janne PA, Yang JC, Kim DW, Planchard D, Ohe Y, Ramalingam SS, Ahn MJ, Kim SW, Su WC, Horn L, Haggstrom D, Felip E, Kim JH, Frewer P, Cantarini M, Brown KH, Dickinson PA, Ghiorghiu S, Ranson M. AZD9291 in EGFR inhibitorresistant non-small-cell lung cancer. N EngI J Med 2015; 372: 1689-1699.

11. Goss G, Tsai CM, Shepherd FA, Bazhenova L, Lee JS, Chang GC, Crino L, Satouchi M, Chu Q, Hida T, Han JY, Juan O, Dunphy F, Nishio M, Kang JH, Majem M, Mann H, Cantarini M, Ghiorghiu S, Mitsudomi T. Osimertinib for pretreated EFGR Thr 790Met-positive advanced non-small-cell lung cancer (AURA2): a multicentre, open-label, single-arm, phase 2 study. Lancet Oncol 2016; 17: 1643-1652.

12. Yang JC, Ahn MJ, Kim DW, Ramalingam SS, Sequist LV, Su WC, Kim SW, Kim JH, Planchard D, Felip E, Blackhall F, Haggstrom D, Yoh K, Novello S, Gold K, Hirashima T, Lin CC, Mann H, Cantarini M, Ghiorghiu S, Jänne PA. Osimertinib in pretreated T790M-positive advanced non-small-cell lung cancer: AURA Study Phase II Extension Component. J Clin Oncol 2017; 35: 1288-1296.

13. Planchard D, Brown KH, Kim DW, Kim SW, Ohe Y, Felip E, Leese P, Cantarini M, Vishwanathan K, Jänne PA, Ranson M, Dickinson PA. Osimertinib Western and Asian clinical pharmacokinetics in patients and healthy volunteers: implications for formulation, dose, and dosing frequency in pivotal clinical studies. Cancer Chemother Pharmacol 2016; 77: 767-776.

14. Sakai $\mathrm{H}$, Hayashi $\mathrm{H}$, Iwasa $\mathrm{T}$. Successful osimertinib treatment for leptomeningeal carcinomatosis from lung adenocarcinoma with the T790M mutation of EGFR. ESMO Open 2017; 2 (Suppl 1): e000104.

15. AZD9291 versus placebo in patients with stage IB-IIIA non-small-cell lung carcinoma, following complete tumor resection with or without adjuwant chemiotherapy (ADAURA). ClinicalTrials.gov Identifier.NCT02511106.
16. Oztan A, Fischer S, Schrock AB. Emergence of EGFR G724S mutation in EGFRmutant lung adenocarcinoma post progression on osimertinib. Lung Cancer 2017; 111: 84-87.

17. Ou SI, Horn L, Cruz M. Emergence of FGFR3-TACC3 fusions as a potential by-pass resistance mechanism to EGFR tyrosine kinase inhibitors in EGFR mutated NSCLC patients. Lung Cancer 2017; 111: 61-64.

18. Uchibori K, Inase N, Araki M, et al. Brigatinib combined with anti-EGFR antibody overcomes osimertinib resistance in EGFR-mutated non-small-cell lung cancer. Nat Commun 2017; 8: 14768.

19. Viola P, Mautya M, Croud J, Gazdova J, Suleman N, Lim E, Newsom-Davis T, Plowman N, Rice A, Montero MA, Gonzalez de Castro D, Popat S, Nicholson AG. A validation study for the use of ROS1 immunohistochemical staining in screening for ROS1 translocations in lung cancer. J Thorac Oncol 2016; 11: 1029-1039.

20. Solomon BJ, Mok T, Kim DW, Wu YL, Nakagawa K, Mekhail T, Felip E, Cappuzzo F, Paolini J, Usari T, lyer S, Reisman A, Wilner KD, Tursi J, Blackhall F; PROFILE 1014 Investigators. First-line crizotinib versus chemotherapy in ALKpositive lung cancer. N Engl J Med 2014; 371: 2167-2177.

21. Blackhall F, Kim DW, Besse B, Nokihara H, Han JY, Wilner KD, Reisman A lyer S, Hirsh V, Shaw AT. Patient-reported outcomes and quality of life in PROFILE 1007: a randomized trial of crizotinib compared with chemiotherapy in previously treated patients with ALK-positive advanced non-small-cell lung cancer. J Thorac Oncol 2014; 9: 1625-1633.

22. Costa DB, Kobayashi S, Pandya SS, Yeo WL, Shen Z, Tan W, Wilner KD. CSF concentration of the anaplastic lymphoma kinase inhibitor crizotinib. J Clin Oncol 2011; 29: e443-e445.

23. Kim DW, Mehra R, Tan DS, Felip E, Chow LQM, Camidge DR, Vansteen kiste J, Sharma S, De Pas T, Riely GJ, Solomon BJ, Wolf J, Thomas M, Schuler M, Liu G, Santoro A, Sutradhar S, Li S, Szczudlo T, Yovine A, Shaw AT. Activity and safety of ceritinib in patients with ALK-reattanged non-small-cell lung cancer (ASCEND-1): updated results from the multicentre, open-label, phase 1 trial. Lancet Oncol 2016; 17: 452-463.

24. Shaw AT, Kim M, Cirno L, Gridelli C, Kiura K, Liu G, Novello S, Bearz A, Gautschi O, Mok T, Nishio M, Scagliotti G, Spigel DR, Deudon S, Zheng C, Pantano S, Urban P, Massacesi C, Viraswami-Appanna K, Felip E. Ceritinib versus chemotherapy in patients with ALK-rearranged non-small-cell lung cancer previously given chemotherapy and crizotinib (ASCEND-5): a randomised, controlled, open-label, phase 3 trial. Lancet Oncol 2017; 18: 874-886.

25. Solange P, Camidge R, Shaw AT, Gadgeel S, Ahn JS, Kim DW, Ou SI, Pérol M, Dziadziuszko R, Rosell R, Zeaiter A, Mitry E, Golding S, Balas B, Noe J, Mor$\cos$ PN, Mok T; ALEX Trial Investigators. Alectinib versus crizotinib in untreated ALK-positive non-small-cell lung cancer. N EngI J Med 2017; 377: 829-838.

26. Thatcher N, Hirsch FR, Luft AV, Szczesna A, Ciuleanu TE, Dediu M, Ramlau R, Galiulin RK, Bálint B, Losonczy G, Kazarnowicz A, Park K, Schumann C, Reck M, Depenbrock H, Nanda S, Kruljac-Letunic A, Kurek R, Paz-Ares L, Socinski MA; SOUIRE Investigators. Necitumumab plus gemcitabine and cisplatin versus gemcitabine and cisplatin alone as first-line therapy in patients with stage IV squamous non-small-cell lung cancer (SQUIRE): an open-label, randomised, controlled phase 3 trial. Lancet Oncol 2015; 16: 763-744.

27. Paz-Ares L, Socinski MA, Shahidi J, Hozak RR, Soldatenkova V, Thatcher N, Hirsch F. 1320 PR: subgroup analyses of patients with epidermal growth factor receptor (EGFR)-expressing tumors in SQUIRE: a randomized, multicenter, open-label, phase III study of gemcitabine-cisplatin (GC) plus necitumumab $(\mathrm{N})$ versus $\mathrm{GC}$ alone in the first-line treatment of patients with stage IV squamous non-small cell lung cancer. J Thorac Oncol 2016; 11 (4 Suppl): S153.

28. Reckamp KL, Brahmer JR, Spigel DR, et al. Phase 3, randomized trial (CheckMate 017) of nivolumab (NIVO) vs docetaxel in advanced squamous (SQ) cell non-small cell lung cancer (NSCLC). J Thorac Oncol 2015; 10 (Suppl. 2): S174.

29. Gralla RJ, Coon C, Taylor F, et al. Evaluation of disease-related symptoms in patients with advanced squamous non-small cell lung cancer treated with nivolumab or docetaxel. J Thorac Oncol 2015; 10 (Suppl. 2): S233.

30. Paz-Ares L, Mezger J, Ciuleanu TE, Fischer JR, von Pawel J, Provencio M, Kazarnowicz A, Losonczy G, de Castro G Jr, Szczesna A, Crino L, Reck M, Ramlau R, Ulsperger E, Schumann C, Miziara JE, Lessa ÁE, Dediu M, Bálint B, Depenbrock $H$, Soldatenkova V, Kurek R, Hirsch FR, Thatcher N, Socinski MA INSPIRE investigators. Necitumab plus pemetrexed and cisplatin as first-line therapy in patients with stage IV non-squamous non-small-cell lung cancer (INSPIRE): an open-label, randomised, controlled phase 3 study. Lancet Oncol 2015; 16: 328-337.

31. Herbst RS, Baas P, Kim DW, Felip E, Pérez-Gracia JL, Han JY, Molina J, Kim JH, Arvis CD, Ahn MJ, Majem M, Fidler MJ, de Castro G Jr, Garrido M, Lubinie 
cki GM, Shentu Y, Im E, Dolled-Filhart M, Garon EB. Pembrolizumab versus docetaxel for previously treated, PD-L1-positive, advanced non-small-cell lung cancer (KEYNOTE-010): a randomised controlled trial. Lancet 2016; 387: 1540-1550.

32. Reck M, Rodriguez-Abreu D, Robinson AG, Hui R, Csőszi T, Fülöp A, Gottfried M, Peled N, Tafreshi A, Cuffe S, O'Brien M, Rao S, Hotta K, Leiby MA, Lubiniecki GM, Shentu Y, Rangwala R, Brahmer JR; KEYNOTE-024 Investigators. Pembrolizumab versus chemotherapy for PD-L1-positive non-small-cell lung cancer. N Engl J Med 2016; 375: 1823-1833.

33. Thungappa S, Ferri J, Caglevic C, Passiglia F, Raez L, Rolfo C. Immune checkpoint inhibitors in lung cancer: the holy grail has not yet been found... ESMO Open 2017; 2: e000162.

34. Borghaei H, Paz-Ares L, Horn L, Spigel DR, Steins M, Ready NE, Chow LQ, Vokes EE, Felip E, Holgado E, Barlesi F, Kohlhäufl M, Arrieta O, Burgio MA, Fayette J, Lena H, Poddubskaya E, Gerber DE, Gettinger SN, Rudin CM, Rizvi N, Crinò L, Blumenschein GR Jr, Antonia SJ, Dorange C, Harbison CT, Graf Finckenstein F, Brahmer JR. Nivolumab versus docetaxel in advanced nonsquamous non-small-cell lung cancer. N Engl J Med 2015; 373: 1627-1639.

35. ESMO. Press release: greater patient selection may be needed for first line nivolumab to improve. Progression-free survival in advanced lung cancer. 2016. Available at: http://www.esmo.org/Conferences/Past-Conferences/ ESMO-2016-Congress/Press-Media/Greater-Patient-Selection-May-beNeeded-for-First-Line-Nivolumab-to-Improve-Progression-free-Survival-inAdvanced-Lung-Cancer

36. Vansteenkiste J, Fehrenbacher L, Spira Al, et al. Atezolizumab monotherapy vs docetaxel in $2 \mathrm{~L} / 3 \mathrm{~L}$ non-small cell lung cancer: primary analysis for efficacy, safety and predictive biomarkers from a randomised phase II study (POLAR). Eur J Cancer 2015; 51 (Suppl 3): S716-S717.
37. Rittmeyer A, Barlesi F, Waterrcamp D, Park K, Ciardiello F, von Pawel J, Gadgeel SM, Hida T, Kowalski DM, Dols MC, Cortinovis DL, Leach J, Polikoff J, Barrios C, Kabbinavar F, Frontera OA, De Marinis F, Turna H, Lee JS, Ballinger M, Kowanetz M, He P, Chen DS, Sandler A, Gandara DR; OAK Study Group. Atezolizumab versus docetaxel in patients with previously treated non-small-cell lung cancer (OAK): a phase 3, open-label, multicentre randomised controlled trial. Lancet 2017; 389: 255-265.

38. Antonia SJ, Villegas A, Daniel D, Vicente D, Murakami S, Hui R, Yokoi T, Chiappori A, Lee KH, de Wit M, Cho BC, Bourhaba M, Quantin X, Tokito T, Mekhail T, Planchard D, Kim YC, Karapetis CS, Hiret S, Ostoros G, Kubota K, Gray JE, Paz-Ares L, de Castro Carpeńo J, Wadsworth C, Melillo G, Jiang H, Huang Y, Dennis PA, Özgüroğlu M; PACIFIC Investigators. Durvalumab after chemoradiotherapy in stage III non-small-cell lung cancer. N Engl J Med 2017; 377: 1919-1929.

39. Reck M, Kaiser R, Mellemgaard A, Douillard JY, Orlov S, Krzakowski M, von Pawel J, Gottfried M, Bondarenko I, Liao M, Gann CN, Barrueco J, GaschlerMarkefski B, Novello S; LUME-Lung 1 Study Group. Docetaxel plus nintedanib versus docetaxel plus placebo in patients with previously treated non-smallcell lung cancer (LUME-Lung 1): a phase 3, double-blind, randomised controlled trial. Lancet Oncol 2014; 15: 143-155.

40. Novello S, Kaiser R, Mellemgaard A, Douillard JY, Orlov S, Krzakowski M, von Pawel J, Gottfried M, Bondarenko I, Liao M, Barrueco J, GaschlerMarkefski B, Griebsch I, Palmer M, Reck M; LUME-Lung 1 Study Group. Analysis of patient-reported outcomes from the LUME-Lung 1 trial: a randomised, double-blind, placebo-controlled, phase III study of second-line nintedanib in patients with advanced non-small cell lung cancer. Eur J Cancer 2015; 51: 317-326. 